Meta

Journal des traducteurs

Translators' Journal

\title{
Bilingual and Multilingual Legal Dictionaries: New Standards for the Future
}

\section{Susan Šarčević}

Volume 36, numéro 4, décembre 1991

URI : https://id.erudit.org/iderudit/004030ar

DOI : https://doi.org/10.7202/004030ar

Aller au sommaire du numéro

Éditeur(s)

Les Presses de l'Université de Montréal

ISSN

0026-0452 (imprimé)

1492-1421 (numérique)

Découvrir la revue

Citer cet article

Šarčević, S. (1991). Bilingual and Multilingual Legal Dictionaries: New

Standards for the Future. Meta, 36(4), 615-626. https://doi.org/10.7202/004030ar
Résumé de l'article

On cherche à faire comprendre et à apprécier la récente méthodologie pour l'élaboration d'ouvrages bilingues ou multilingues de terminologie juridique. On traite d'abord des problèmes du transfert interlangue en lexicographie juridique, puis on expose des méthodes visant à faire augmenter la confiance des utilisateurs de tels ouvrages. Enfin on discute des avantages et des désavantages de différentes solutions lors de l'absence d'équivalent. 


\title{
BILINGUAL AND MULTILINGUAL LEGAL DICTIONARIES: NEW STANDARDS FOR THE FUTURE ${ }^{1}$
}

\author{
SUSAN S̆ARČEVIć \\ University of Rijeka, Rijeka, Yugoslavia
}

\begin{abstract}
Résumé
On cherche à faire comprendre et à apprécier la récente méthodologie pour l'élaboration d'ouvrages bilingues ou multilingues de terminologie juridique. On traite d'abord des problèmes du transfert interlangue en lexicographie juridique, puis on expose des méthodes visant à faire augmenter la confiance des utilisateurs de tels ouvrages. Enfin on discute des avantages et des désavantages de différentes solutions lors de l'absence d'équivalent.
\end{abstract}

\section{INTRODUCTION}

Twenty-five years ago lexicographers regarded the task of compiling bilingual legal dictionaries as nearly impossible. Aware that their equivalents were no more than mere approximations, legal lexicographers sometimes reassured their users that they were nevertheless the best approximations. Others, however, warned users to proceed with caution, thus hoping to save themselves from being pilloried traduttore traditore. Disturbed by the low reliability of bilingual legal dictionaries, René David denounced them as inevitably inaccurate, insisting that word pairs cited as equivalents were often misleading to the point of being dangerous (1974: 346).

Since David's detrimental criticism in 1974, efforts on the part of lexicographers to improve user reliability have led to new methods of combating the special problems of interlingual transfer encountered in the field of law. As a result, new standards for the future have been established. Thus it can be said that legal lexicography has finally come of age, or as J.-C. Gémar put it: "A special method in legal lexicography has been established" (written communication of 13 May 1986; see also Gémar 1986: 448-453).

\section{PROBLEMS OF INTERLINGUAL TRANSFER}

In order to understand and appreciate the new methodology, one must be aware of the special challenge of legal lexicography. As a rule, the search for equivalents in law initiates as a search for the closest equivalent concept in the legal reality of the TL (target language). This is known as a functional equivalent, i.e., a corresponding term in the TL designating a concept or institution, the function or usage of which is the same as that of the source term. Ideally, the conceptual features of the equivalent should correspond exactly with those of the SL (source language) concept. However, exact equivalence in this sense can never be fully achieved (Nida 1975: 120), and thus lexicographers must be content with basic equivalence instead. Unlike other fields of specialized lexicography, especially the natural sciences and technology, in law even basic equivalence is difficult to achieve. Due to differences in the legal systems, cultures and languages in question, 
the degree of semantic equivalence between the legal terminology of two countries is greatly restricted. Accordingly, the conceptual features of corresponding word pairs are usually only partially equivalent.

The use of functional equivalents in law has thus been aptly described as translation by analogy (Pigeon 1982: 280), which presupposes partial equivalence without a guarantee of basic equivalence at the conceptual level. This is especially true in the case of technical terms which are system-bound. For historical reasons, different legal systems with distinct characteristics have developed, notably common law and civil law. The differences between these two systems are sometimes so great that a functional equivalent may be similar to the source concept only as far as its general function or usage is concerned, whereas the legal concept it denotes in the restricted sense is different.

Unable to find adequate equivalents for technical terms, legal lexicographers used to warn their users to refrain from reading the notions of the source terms into the equivalent. Whenever possible, several near synonyms were cited in addition to the functional equivalent. Frequently, these terms were more general so as to focus on the conceptual similarity between the functional equivalent and the source concept. According to the usual practice, the string of potential equivalents was separated by commas. This, however, implied that the terms were true synonyms and thus proved to be misleading.

It should also be pointed out that even general legal concepts may be misleading. This is due to the fact that the level of generality of legal concepts tends to vary. For example, the concept of décision in French corresponds with two, more specific concepts in German Entscheidung, Beschluss, and three in Dutch Beschikking, Besluit, Beshlissing (Bauer-Bernet's examples 1982: 192).

Furthermore, interlingual transfer is made more complicated by the fact that the language of the law is polysemous. Contrary to the exact sciences, it sometimes occurs that the same term is used in a different sense in different laws or takes on a new meaning as a result of court interpretation (cf. Weisflog 1987: 208-209). As a rule, lexicographers simply used semicolons to separate the various equivalents into groups corresponding to the different meanings of a polysemous source term. Accordingly, a reader who was not familiar with the terms was obliged to consult a monolingual law dictionary before making a choice among the groups of potential equivalents.

The same often applied when there is diversity in the geographical usage of TL terms. Although English is the major language of the common law countries, they do not have a uniform legal terminology. Not only do American and British terms vary, but within the United Kingdom itself there are considerable differences in the legal terminology of England, Northern Ireland, and particularly Scotland, whose legal system is a mixture of common law and civil law. The same is true in civil law countries or regions where the same language is spoken, especially Spanish, German and French but also Dutch. The problems of interlingual transfer become even more complex in countries with bilingual legislation and dual legal systems, for example, Canada, South Africa and, to a certain extent, Israel.

\section{METHODS OF IMPROVING USER RELIABILITY}

The first obvious step towards achieving a greater degree of accuracy has been to include brief definitions of the source institutions and concepts as well as explanatory notes on comparative law. In the case of polysemous terms, the field of usage is often indicated or there may be a separate entry for each meaning. Even in some specialized dictionaries, the terms are grouped into smaller areas of specialization. Ursula Becker's 
Rechtswörterbuch für die gewerbliche Wirtschaft, for example, contains 15 subdivisions covering specialized areas of commercial law, e.g., conditions of purchase, sale and delivery; agency contracts; exclusive dealer arrangements; licensing agreements; unfair competition; taxation, etc.

Today, legal dictionaries are usually reference books with a more or less elaborate documentary apparatus. In some cases detailed definitions of both the source term and its equivalent are given. Consequently, it is becoming increasingly difficult to differentiate between ordinary and encyclopedic dictionaries such as Francesco de Franchis' Dizionario giuridico inglese-italiano, a scholarly work totaling 1545 pages, including a 250 page introduction on usage and a 60 page bibliography of works cited in the text (see Reynolds 1986: 552).

\section{PLACING MEANING IN CONTEXT}

Plagued by the problems of ambiguity inherent in legal terminology, bilingual lexicographers began to document their entries with contextual data. In numerous cases, the term in question is cited as a collocation taken directly from the source text, which is usually a law or other legal instrument. This is the common practice, for example, in the legal glossaries prepared by terminology divisions of the European Communities (EC) such as the Court of Justice and the European Parliament. In exceptional cases, the entire sentence of the source text is cited, e.g. in the Vocabulaire bilingue de la Common law prepared by the Canadian National Program for the Integration of the Two Official Languages in the Administration of Justice (hereinafter: Canadian National Program). Regardless of the method used, the exact reference is cited by a predefined code or system of abbreviations, thus enabling the user to consult the source text, e.g.: "Anknüpfungspunkt zum Gemeinschaftsrecht/Lien de rattachement avec le droit communautaire (48/75Rec.1976;510)" (in LeTellier 1985: 10).

The task of supplying contextual data becomes more difficult when the source text is not a bilingual or multilingual document. In such cases the sources of the SL and TL terms differ, thus requiring that dual references be cited. This is especially useful since it proves the authenticity of both the source term and its equivalent. As early as 1978, bilingual references were cited in the Dictionnaire juridique néerlandais-français avec vocabulaire français-néerlandais (Droit privé) prepared by the T.M.C. Asser Institute of The Hague (Tebbens 1982: 176-179).

\section{DIVERSITY OF USAGE}

Previously it was not uncommon for lexicographers to state in the introduction that their equivalents were restricted to a certain geographical area, for example, to the Spanish in Spain. On the other hand, if diversity of usage was taken into account, the TL variants were identified by indicating the respective country or region of usage. Today, this practice has been expanded to include explanatory notes and sometimes even charts or entire pages. In this context it is worthwhile to mention the United Nations glossary Derechos Humanos (Spanish-English-French) which contains a chart listing variation in the basic terminology of criminal procedure used in 13 Spanish-speaking countries (1985: vii),

Some bilingual legal dictionaries may devote special attention to usage to the extent that they resemble a dictionary of usage. This may be said, for example, of J.A. Clarence Smith's forthcoming Dictionnaire juridique français-anglais, anglais-français which is being prepared under the sponsorship of the Quebec Ministry of Justice. Although most of the French terms are "universal French," as the author refers to them, legal terms used strictly in Quebec and elsewhere in Canada are also included. Moreover, 
diversity in the use of English terms is indicated by specifying the place of usage: North American or Great Britain, or more specifically, the United States, Canada, Quebec, England or Scotland. Whenever the legal terminology used in Canadian bilingual legislation differs from the above, these terms are also noted. Finally, terms which are archaic are marked as such and additional information is included on the terminological evolution presently taking place in Quebec (Smith forthcoming: i-xii).

\section{ACCEPTABILITY OF FUNCTIONAL EQUIVALENTS}

Another method of improving user reliability involves establishing a criterion to measure the acceptability of functional equivalents. For the sake of accuracy, it is generally agreed that there is a certain point beyond which a functional equivalent can no longer be considered acceptable. As of yet, however, no consensus has been reached as to where this point actually is. On the one hand, the so-called functionalists insist that a functional equivalent is acceptable as long as the concept it denotes has the same general function as the source concept (Pigeon 1982: 280). Whereas the functionalists are willing to disregard the legal concept in its restricted sense, their opponents argue that a functional equivalent is acceptable only "as long as the corresponding equivalent has the same legal meaning" (Snow: written communication of May 1986; Duchesne: written communication of 15 May 1986).

While the Canadians have been preoccupied with domestic differences of opinion concerning the acceptability of functional equivalents, the members of the Internationales Institut für Rechts- und Verwaltungssprache in Berlin (hereinafter: Berlin Institute) have established a criterion for determining minimum acceptability which could perhaps be regarded as a compromise solution.

About 15 years ago the Berlin Institute began using methods of comparative conceptual analysis to evaluate the accuracy of functional equivalents for use in its Europaglossar der Rechts- und Verwaltungssprache, a series consisting of 28 glossaries published since 1966 (see list in Lane 1982: 231). According to A. Lane, the first step of the analysis is to determine the conceptual characteristics of the source concept. In a simplified example, he describes the conceptual characteristics of the concept of appeal under English law as follows:

A. Legal proceedings aimed at bringing about a complete or partial annulment or amendment of a judgment delivered by a court.

B. The effect of an appeal once it has been duly lodged is to

a) postpone the coming into force of the judgment (suspensive effect), or

b) have the case sent to a higher court for a decision (devolutionary effect).

C. An appeal is directed against the actual findings and the legal conclusions of judgment.

D. To be valid, an appeal must adhere to certain formal requirements (it must be submitted in writing to the proper court within a specified period of time: judex a quo or judex ad quem).

E. The entire case is tried again, both from the factual and the legal standpoint, in the court of appeal. (1982: 224)

These characteristics are then divided into two groups - essentialia and accidentalia - depending on whether the particular conceptual feature is essential. Thereafter, the same process is repeated for the TL equivalents, e.g., Berufung in German, appel in French, apelacion in Spanish. The final evaluation is essentially a process of matching up the corresponding characteristics. If all the essential characteristics of the source concept match up with those of the functional equivalent and only a few of the accidentalia do 
not, the concepts are considered to be basically "identical." In such cases the mathematical symbol " $="$ precedes the entry, expressing a state of basic equivalence. On the other hand, if most of the essentialia and only some of the accidentalia are the same, the concepts are regarded as only "similar" and the symbol " + " is used to indicate partial equivalence. Finally, if only a few or none of the essential features of the source concept and the functional equivalent coincide, the two concepts are considered nonequivalent. In such cases, the functional equivalent is discarded and the symbol " $\neq$ " designates the lack of an acceptable functional equivalent (Lane 1982: 224-225).

According to the three categories above, minimum acceptability requires that most of the essential features of the source concept and the functional equivalent match up, not merely the general function or usage as proposed by the functionalists. On the other hand, the Berlin Institute does not go to the other extreme of requiring basic equivalence for acceptability. By proposing partial equivalence as a measure of minimum acceptability, the Institute offers a more flexible criterion. At the same time, it also establishes a lower limit to show where partial equivalence ends and non-equivalence begins.

At this point it should be noted that the question of whether partial equivalence suffices for acceptability is not purely a legal matter but also involves two basic principles of lexicography: the purpose of the dictionary and the intended readership. Generally speaking, partial equivalence is sufficient in dictionaries written exclusively for information purposes and intended for readers of diverse legal realities. On the other hand, there are also dictionaries whose sole purpose is to standardize terminology, for example, for domestic use in bilingual legislation. Since their main concern is accuracy, it is only natural that these lexicographers are satisfied with nothing less than basic equivalence. This is the case, for example, in the CLEF vocabularies (Common law en français) prepared by the Canadian National Program.

Turning to the bilingual and multilingual glossaries of international organizations such as the UN and UN-related bodies, we see that their claim to accuracy varies according to their specific purpose. Since the equivalents in the glossaries compiled by the Language Services of the UN are intended for use in authentic documents and legal instruments, it follows that they must basically correspond with the source concepts in order to be acceptable. Accordingly, the term habeas corpus is rejected as an equivalent for the Spanish term amparo, which, in its widest sense, is usually broader than the concept of habeas corpus (Derechos Humanos 1985: 10).

\section{ALTERNATIVE EQUIVALENTS}

This brings us to another problem which has become a point of controversy in legal lexicography. What happens if a functional equivalent is unacceptable or if there is no functional equivalent at all for a particular source concept? In such cases, legal lexicographers are usually content to define or paraphrase the source term. Those who insist on offering an equivalent for every term, for example, for the purpose of translation, are forced to use one of the following types of equivalents: borrowings, literal equivalents, descriptive substitutes, neologisms.

\section{BORROWINGS}

In order to avoid possible misunderstandings, legal lexicographers sometimes use borrowings as a last resort; in other words, the source term is simply borrowed into the TL. For example, the UN Derechos Humanos glossary cites the term amparo as a borrowing with the following instruction to translators: "Leave in Spanish, underline and add in parenthesis 'enforcement of constitutional rights'..." (1985: 10). 
As a result of the constant contact of the two legal systems in Canada, English common law terms and French civil law terms are often borrowed into the other language. For example, the French terms succession and obligation appear unchanged as borrowings in the English version of the Civil Code of Lower Canada (e.g., see chapters three and six). Due to their common Latin etymology the meanings of these borrowings are sufficiently transparent even to those who are not familiar with the civil law source terms. In most cases, however, the reader must already understand the source terms in order for interlingual transfer to be completed. For example, if the reader is not familiar with the technical common law term affidavit, the borrowing will mean nothing to him unless an adequate definition is supplied. Since borrowings of technical terms are usually not understood by outside readers, their use should be limited to dictionaries and glossaries intended strictly for domestic use.

Sometimes the source term is naturalized into the TL. Naturalized words are borrowings which have been modified phonologically or graphologically so as to be more similar to the native words of the TL (according to Pei and Gaynor 1980: 145). Naturalizations of English common law terms into French are common in the bilingual provinces of Canada, e.g., aviseur légal for legal adviser and entreplaiderie for interpleader. As a rule, borrowings of this sort should be avoided whenever an acceptable equivalent already exists. In this sense J.A. Clarence Smith argues against the use of aviseur légal, insisting that the functional equivalent conseiller juridique is acceptable and should thus be used instead (1983: 598). Moreover, a term should not be naturalized into the TL if the same expression already has a specific meaning in the legal terminology of the TL. Accordingly, Smith points out that the term entreplaiderie already exists in French law and thus rejects using the same term as a naturalization for interpleader (1983: 602; 1984a: 743).

Generally speaking, lexicographers should restrict their use of naturalizations to borrowings which have already been naturalized into the TL (Šarcevic 1985: 128). Although French-speaking Canadian jurists often succumb to the habit of anglicizing expressions in daily communication, there are arguments against incorporating such anglizations into the standard language. Once they have become part of the standard language, it is extremely difficult to purge the language of them. This can be witnessed in Quebec where a terminological evolution is presently taking place to rid the French legal language of anglizations (Smith 1983: 604-606; on linguistic borrowing in Quebec see Russell 1979: 215-217). Although this tendency has met with resistance in the predominantly English-speaking common law provinces, it appears that even here there is a conscious attempt to use naturalizations and other borrowings only as a last resort.

Finally, the use of borrowings depends not only on the intended readership but also on the SL in question, a fact which is often overlooked. As a rule, legal terms of languages of limited diffusion are not borrowed into the TL (Šarčević 1985: 129).

\section{LITERAL EQUIVALENTS}

Many bilingual lexicographers prefer to use literal equivalents whenever the source term is semantically motivated or transparent (cf. Newmark 1982: 75). As a rule, a literal equivalent should be used only if the term in question does not already have a specific meaning in the legal reality of the TL. Since this "can be done only on rare occasions" (Bastarache and Reed 1982: 207), the acceptability of certain literal equivalents is often disputed. As a result, acceptability may depend not only on the language in question but also on the subjectivity of the lexicographer regarding the importance of the particular term for his own system. For example, Canadian lexicographers unanimously agree that, for the sake of accuracy, the term common law should be cited as a borrowing in French (Bastarache and Reed 1982: 213; Smith 1984b: 760; David agrees with the Canadians, 
1974: 345-346). On the contrary, other lexicographers often prefer to use the literal equivalent droit commun (e.g., in Herbst 1979: 205; LeDocte 1978: 194-195; Egbert and Morales-Macedo 1979: 150).

Although Canadians generally use a large number of literal equivalents, there are sometimes differences of opinion among themselves as to their acceptability. For example, the functionalists flatly reject the French literal equivalents bien réel and bien personnel for the common law terms real property and personal property. Whereas the terms réel and personnel make good sense in French, they insist that they have no meaning at all when combined with the term bien (Pigeon 1982: 280; Smith 1984b: 755-756). Nevertheless, the National program has chosen to recognize the literal equivalents which, in this case, were already in usage in New Brunswick and Manitoba.

The Canadians justify their choice of such literal equivalents on the ground that their standardized terms are intended strictly for domestic use. Although they do not expect outsiders to use, their literal equivalents, they generally agree that outside readers should nevertheless be able to identify the source term by back translation, which is usually sufficient for the completion of interlingual transfer. This, however, presupposes that the literal equivalent is reasonably understandable.

\section{DESCRIPTIVE EQUIVALENTS}

In cases where a literal equivalent is unacceptable or clearly impossible, lexicographers sometimes use a descriptive equivalent, i.e., an expression which describes the term or function of the institution or concept in question (Sarcevic 1985: 132). For example, the glossary on Kraftfahrtversicherung prepared by the Berlin Institute lists the equivalent "third party" cover for the source term Haftpflichtdeckung. The use of the descriptive substitute third party is clarified by the definition, which informs the reader that the main function of the German concept "is to cover the policyholder against his liability for the death of or bodily injury to other persons and for damage to third party property" (1980: 45).

Some languages lend themselves to description more readily than others. This is particularly true of the Sino-Tibetan languages such as Chinese. As a rule, the meanings of Chinese words are transparent, which can perhaps be explained by the fact that written Chinese uses ideograms instead of letters or syllable signs. For example, the back translation of the Chinese term for Rechtsanwalt (律师 (做) lùshì) may be rendered as Gesetzesmeister or Gesetzesfachmann (in Xin Han-DeCidian 1985: 15). Thus it is not surprising that a large number of Chinese equivalents for Western legal terms are also descriptive.

Descriptive equivalents should always be accompanied by definitions and explanatory notes in order to assure at least a minimum level of understanding. This is particularly true when there are considerable differences in the legal systems, cultures, and languages in question.

\section{NEOLOGISMS}

Some lexicographers believe that it is up to them to create a new term if they cannot find an acceptable equivalent in the TL. Neologisms may be created either by introducing a new word into the TL or by borrowing a TL term already in existence and assigning it a new meaning (Pei and Gaynor 1980: 146; cf. Wijnands 1985: 15). On the other hand, German linguists generally regard only Neubildungen as neologisms (cf. Abraham 1974: 290; Fleischer 1975: 14, note 19). Although the use of neologisms is highly disputed in legal lexicography, the view prevails that the lexicographer's task is to 
"record," not to "create" terminology (LeTellier: written communication of 12 June 1986; cf. Weston 1983: 209).

In particular, the language services of the UN reject the creation of neologisms, advocating the use of borrowings instead. Accordingly, only neologisms which have already been verified by the competent national institution, e.g., the Association française de normalisation (AFNOR), are included in UN glossaries. In the case of legal terminology, neologisms for new concepts in international law are usually created by the International Law Commission (ILC) or the UN Commission on International Trade Law (UNCITRAL) in the process of drafting international conventions. For example, the term continental shelf, which was originally a geographic term, was adopted by the ILC to designate a concept related to the law of the sea. Its legal criteria, which completely disregard the meaning intended by geographers, are defined in the text of the UN Convention on the Law of the Sea (Tabory 1980: 133).

For the most part, the same is true as far as the European Communities are concerned. As a result of the development of Community Law, which has an intermediate position between national and international law, new legal terms are created to designate conceptual innovations. Only in exceptional cases are existing national legal terms used to designate new Community concepts. In such cases, the new meaning must be clearly defined in the particular legal instrument. Whenever the term is used, specifying words should be added in brackets to avoid confusion (Losson: written communication of 24 July 1986). Nevertheless, this type of neologism is not always satisfactory, and thus drafters sometimes create a new legal expression in order to avoid using a purely national term. For example, the expression acquis communautaire and its equivalents community patrimony and Gemeinschaftsbesitzstand were coined to denote "all Community Acts adopted under the Rome Treaties and all decisions taken since establishment of the Communities" (Losson: written communication of 24 July 1986). It should be noted that neologisms of this sort are created only if strictly necessary. (According to LeTellier, literal equivalents clearly have priority: written communication of 12 June 1986; cf. Bauer-Bernet 1982: 192.)

Generally speaking, Canadian legal lexicographers also approve of the creation of neologisms as a method of last resort. In addition to the two types of neologisms already mentioned, revived archaisms are also regarded as neologisms by some French linguists (Mounin 1974: 229-230; see Wijnands 1985: 13-36). In view of this, it is not surprising that Canadian lexicographers take archaic terminology into account during their search for equivalents. This includes archaisms of the ordinary language as well as legal terms. For example, the French term préclusion, which was widely used in the fifteenth and sixteenth centuries, has been proposed as an equivalent for the common law term estoppel. Although the word préclusion can no longer be found in contemporary French dictionaries, according to Bastarache and Reed, it is used in international law today. Nevertheless, the decision to adopt the expression as an equivalent for a common law term, which is strictly a concept of private law, is based primarily on the archaic meaning of the word as an act of stopping or deferring (1982: 213-215).

It should be pointed out that there are practical reasons behind the Canadians' decision to incorporate neologisms into their new vocabularies of common law terms in French. In this case, the lexicographers are deliberately taking it upon themselves to establish TL terms for standardization purposes. Generally speaking, the creation of neologisms in such exceptional cases is permitted provided there is no acceptable equivalent already in existence. As Weston has pointed out, "neologisms must not be created by default - through laziness of inadvertence" (1983: 209). 


\section{CONCLUDING REMARKS}

Since the founding of the International Organization for Standardization (ISO) there has been increasing emphasis on the unification and standardization of terminology, especially in the fields of exact sciences. In view of the fact that unification requires harmonization of divergent definitions and systems of concepts, the majority of bilingual and multilingual legal dictionaries are not intended for standardization purposes. An exception, as mentioned above, is the Canadian National Program's CLEF series which standardizes terms strictly at the national level.

The enactment of the Canadian Official Languages Act in 1969 led to a sudden increase in the use of common law terminology in French, particularly in the common law provinces of Manitoba, NewBrunswick and Ontario. Fearing that the numerous terminological inconsistencies would endanger uniform interpretation by the courts, the Canadian Ministry of Justice, the Secretary of State Department and the three provinces mentioned above founded the National Program in 1982. In 1984 the first two volumes of the CLEF series, Droit de la preuve and Droit successoral were published, in 1986 a third volume on Droit des biens.

In the introduction to the first volume, it is emphasized that the French equivalents are intended "to cover the same concepts" as the English common law terms to which they are matched (1984: xii). This means, among other things, that even functional equivalents are to be interpreted in the sense of the source term. Since the criterion for the minimum acceptability is basic equivalence, the use of functional equivalents is kept to a minimum in order to avoid creating "a distorted picture of the legal system or situation being dealt with" (xi). As to the question whether the vocabularies will be authoritative, the Chairman of the National Program admits that the "decisions on standardization cannot be binding on all who use "common law in French"" (viii). Whereas "the members of the Standardization Committee, all of whom have decision-making roles in the drafting or translation of legislation..., are committed to using the standardized terms in the future," it can only be hoped "that it will also be used by judges, practising lawyers, notaries, law professors, jurists in general and translators" (viii). Furthermore, it is emphasized that "the practical value of a legal vocabulary comes primarily from the consensus on terminology that develops among users" (viii). Accordingly, the success or failure of a standardization program depends largely on the degree of user resistance. This is true not only at the national but also at the regional and international levels.

In the United Nations, the Council of Europe and the European Communities, the greatest resistance to standardization comes from the users. "Overburdened" by their own legal background, language structure and cultural behavior, jurists tend to resist any interference or change (LeTellier: written communication of 12 June 1986). Although a specific Community jargon has developed within the EC, especially in areas of economic law (Bauer-Bernet 1982: 190), the basic linguistic policy of the EC clearly endorses the prerogative of the member states to use their own language. Consequently, there are no official standardization activities in the European Communities. Even Community glossaries tend to have only semi-official status (Losson: written communication of 24 July 1986). Moreover, the equivalents listed in their multilingual glossaries based on translations of Community conventions, treaties, decisions, rules and regulations are sometimes plagued by inaccuracy and inconsistency (Gémar 1984: 323-325).

Its counterpart, the CMEA (Council of Mutual Economic Assistance), has made conscious efforts to unify terminology in order to promote "the exchange of ideas and goods" (Felber 1984: 25). CMEA terminology standards, which are published in the languages of the member countries, are set up primarily by the Vsesojuznyj NaučnoIssledovatel'skij Institut Techničeskoj Informacii, Klassifikacii i Kodirovanija (VNIIKI) in 
Moscow, which coordinates the standardization of terminology in the USSR (VNIIKI 1978: 1-48). As is to be expected, the results have been the most effective in areas of economic law.

Although international conventions, standard form contracts, contract conditions and other legal instruments standardize international trading practices, one should keep in mind that this does not necessarily mean that the terminology contained therein has also been standardized. In numerous cases it has not even been unified. At present the unification of legal terminology is still in its initial stage, particularly at the international level.

According to I. Paenson, who spent 17 years compiling his Manual of the Terminology of Public Law (Peace) and International Organization, the main problem in achieving unification is not so much in finding accepted equivalents in other languages as in the fact that the definitions of legal terms are controversial (1983: xv). Attempting to overcome this problem, Paenson has gathered legal terms whose definitions have been unifed by international conventions and other legal instruments. Instead of listing the terms in individual entries in alphabetical order, he groups them according to subject matter, presenting the same source text in four parallel columns: English, French, Spanish and Russian. The source text, which is descriptive and verges on the encyclopedic, contains supplementary definitions or explanations in brackets whenever necessary. By making it possible to compare terms whose meaning is equivalent and whose authenticity has been confirmed by legal experts of the respective languages, it is hoped that Paenson's manual will contribute to the unification of the terminology of international law (see preface: $x i$ ).

In conclusion it can be said that in theory the unification and even the standardization of legal terminology is conceivable; in practice, however, it is extremely difficult to achieve consensus among users. Whereas the new methodology of bilingual and multilingual lexicography has succeeded in improving user reliability, the question as to whether it will also promote the unification and eventually standardization of legal terminology will depend primarily on the users.

\section{NOTES}

1. The author presented a paper on this subject matter at the EURALEX International Congress, Zurich, 1986; see ZüriLEX' 86 Proceedings.

2. My thanks go to the following persons who contributed to this research by written communication or interview: Michel Beaupré, Assistant Law Clerk and Parliamentary Counsel (Ottawa), André Collin, chef du Service des terminologies sectorielles, Office de la langue française (Québec); Andrée Duchesne, Technical Committee of the National Program on Integration of the Two Official Languages in the Administration of Justice (Ottawa); Jean-Claude Gémar, professeur titulaire et jurilinguiste, Université de Montréal; Ian Hamilton, Head of Terminology Division of the U.N. Language Service (Geneva); Lucie Laguë, Quebec Research Centre of Private and Comparative Law, McGill University, Gérard Losson, jurilinguiste, Conseil des communautés européennes (Bruxelles); Rejean Patry, Co-ordinator of the National Program on Integration of the Two Official Languages in the Administration of Justice (Ottawa); A. Rohaert, Head of Terminology Office, European Parliament (EC) (Luxembourg); Harro von Senger, Schweizerisches Institut für Rechtsvergleichung/Universität Zürich; J.A. Clarence Smith, ministère de la Justice, Québec; Gérard Snow, directeur du Centre de traduction et de terminologie juridiques de l'Université de Moncton; Jacques LeTellier, chef du Service de terminologie, Cour de justice des Communautés européennes (Luxembourg); A.Werner, Head of Translation Division of the U.N. Language Service (Geneva); Martin Weston, translator, Council of Europe (Strasbourg).

\section{BIBLIOGRAPHY}

\section{- CITED DICTIONARIES}

Derechos Humanos/Human Rights/Droits de l'homme (1985): Language Service of the United Nations at Geneva.

HERBST, R. (1979): Dictionary - Commerce, Finance, Law (English-German-French), Zug, Translegal Ltd., vol. 1.

CLARENCE SMITH, J.A. (forthcoming): Dictionnaire juridique, français-anglais, anglais-français. 
Dictionnaire juridique néerlandais-français avec vocabulaire français-néerlandais, droit privé (1978): T.M.C. Asser Institute, Amsterdam \& Anvers.

Dictionnaire de termes juridiques en quatre langues (1978): E. LeDocte, Bruxelles, Oyez.

DEFRANCHIS, F. (1984): Dizionario Giuridico Inglese-Italiano, Milano, Giuffrè.

Kraftfahrtversicherung, (Deutsch-Englisch) bd. 27 (1980): Europa-Glossar der Rechts- Und verwaltungssprache, Internationales Institut für Rechts- und Werwaltungssprache, Berlin/München/Wien/Zürich, Langenscheidt.

Manual of the Terminology of Public International Law (Peace) and International Organizations (EnglishFrench-Spanish-Russian) (1983): I. Paenson, Brussels, Bruylant.

EGBERT, L.D. and F. MORALES-MACEDO (1979): Multilingual Law Dictionary, New York, Oceana.

HAN-DE CIDIAN, Xin (1985): Das Neue Chinesisch-Deutsche Wörterbuch, Bejing, Shangwu Yinshuguan.

BECKER, U. (1980): Rechtswörterbuch für die Gewerblich Wirtschaft, Frankfurt \& Paris, Fritz Knapp, La Maison du dictionnaire.

Vocabualire bilingue de la common law: Droit de la preuve, droit successoral (Common Law en français = La clef) (1984): Programme d'administration de la justice dans les deux langues officielles, Ottawa.

LETELLIER, J. (1985): Vocabulaire de la Cour de justice des Communautés européennes allemand-français, Luxembourg.

- OTHER LITERATURE

ABRAHAM, Werner (1974): Terminologie zur neueren Linguistik, Tübingen, Niemeyer.

BASTARACHE, Michel and David REED (1982): «La nécessité d'un vocabulaire français pour la Common law», J.-Cl. Gémar (réd.), Langage du droit et traduction, Montréal, Linguatech/Conseil de la langue française, pp. 217-281.

BAUER-BERNET, Hélène (1982) : «Le multilinguisme du droit de la Communauté européenne», J.-Cl. Gémar (réd.), Langage du droit et traduction, Montréal, Linguatech/Conseil de la langue française, pp. 187-197.

DAVID, René (1974): Les grands systèmes de droit contemporains, 6 éd., Paris, Dalloz.

FELBER, Helmut (1984): Terminology Manual, Paris, UNESCO and Infoterm.

FLEISCHER, Wolfgang (1975): Wortbildung der deutschen Gegenwartssprache, Tübingen, Niemeyer.

GÉMAR, Jean-Claude (1986): «Une première canadienne : le Dictionnaire de droit privé», dans les Cahiers de droit 27-2, pp. 437-461.

GÉMAR, Jean-Claude (1984): Revues de Terminologie de l'avant-projet de convention relatif à un droit européen des marques (1981), $2^{\mathrm{e}}$ éd., Parlement européen; et Terminologie du brevet européen (1981), Parlement européen; et Terminologie de la société anonyme européenne (1981), $3^{\mathrm{e}}$ éd, Parlement européen, Meta, 29-3, pp. 323-326.

LANE, Alexander (1982): "Legal and Administrative Terminology and Translation Problems," J.-Cl. Gémar (éd.), Langage du droit et traduction, Montréal, Linguatech/Conseil de la langue française, pp. 219-231.

MOUNIN, Georges (1974): Dictionnaire de la linguistique, Paris, PUF.

NEWMARK, Peter (1982): Approaches to Transiation, Oxford, Pergamon Press.

NIDA, Eugene A. (1975): Exploring Semantic Structures, chap. 9, "Analysis of Meaning and Dictionary Making," München, Wilhelm Fink.

PEI, Mario and Frank GAYNOR (1980): A Dictionary of Linguistics, Totowa, New Jersey, Littlefield, Adams $\& \mathrm{Co}$.

PIGEON, Louis-Philippe (1982): "La traduction juridique - l'équivalence fonctionnelle", J.-Cl. Gémar (réd.), Langage du droit et traduction, Montréal, Linguatech/Conseil de la langue française, pp. 271-281.

REYNOLDS, Thomas (1986): "Comparative Legal Dictionaries," American Journal of Comparative Law, 34-3, pp. 551-558.

RUSSELL, Robert (1979): "The Statutes of Quebec: Linguistic Interference," Meta, 24-1, numéro spécial: La Traduction juridique, pp. 213-217.

S̆ARČEVIĆ, Susan (1985): "Translation of Culture-bound Terms in Laws," Multilingua, 4-3, pp. 127-133.

SMITH, J.A. Clarence (1983): «La Common Law en français», The Canadian Bar Review 61, pp. 595-608.

SMITH, J.A. Clarence (1984a): Revues de Vocabulaire de la Common Law : Droit des biens - Procédure civile (1980), Droit des fiducies (1982) et Procédure civile - Preuve (1983), par le Centre de traduction et de terminologie juridiques de l'Université de Moncton, publiés par les Éditions du Centre universitaire de Moncton, The Canadian Bar Review 62, pp. 741-746.

SMITH, J.A. Clarence (1984b): «Droit comparé et terminologie comparée», Revue de la recherche juridique droit prospectif 3 , pp. 755-761

TABORY, Mala (1980): Multilingualism in International Law and Institutions, Alphen aan den Rijn, Sijthoff \& Noordhoff.

TEBBENS, Harry (1982): «Le dictionnaire juridique néerlandais : un exercice de droit comparé», J.-Cl. Gémar (réd.), Langage du droit et traduction, Montréal, Linguatech/Conseil de la langue française, pp. 173-185.

VNIIKI (1978): Standardizacija terminologii v SSSR i meždunarodny organizacijah, Moskva. 
WEISFLOG, W.E. (1987): "Problems of Legal Translation," Swiss Reports Presented at the XIIth International Congress of Comparative Law, Zürich, Schulthess, 179-218.

WESTON, Martin (1983): "Problems and Principles in Legal Translation," The Incorporated Linguist 22-4, pp. 207-211.

WIJNANDS, Paul (1985): «Pour une redéfinition du néologisme lexicographique», La Banque des mots 3 , pp. 13-34. 